\title{
Evaluation of horizontal resistance of sunflower (Helianthus annuus L.) to downy mildew (Plasmopara halstedii) ${ }^{\text {is }}$
}

\author{
Sergey Gontcharov ${ }^{1, *}$ (D) and Natalya Goloschapova ${ }^{2}$ \\ ${ }^{1}$ Kuban State Agrarian University, Department of Genetics, Plant Breeding and Seed Production, Kalinina, 13, Krasnodar 350044, Russia \\ 2 V.S. Pustovoit All-Russian Research Institute of Oil Crops (VNIIMK), Department of Hybrid Sunflower Breeding, Filatova, 17, \\ Krasnodar 350038, Russia
}

Received 15 September 2021 - Accepted 18 November 2021

\begin{abstract}
Downy mildew is one of the most important diseases of sunflower crop around the world caused by Plasmopara halstedii (Farl.) Berl.et de Toni. The aim of our study was to evaluate the horizontal resistance of elite and prospective lines to downy mildew in field conditions. Experiments were conducted at All-Russia Research Institute of Oil Crops (VNIIMK) in 2016-2020. Released and prospective sunflower lines bred at VNIIMK were studied, divided into four groups on the base of their race-specific resistance in laboratory tests. Experimental design was randomized blocks with two replications. Evaluation was made by recording all the recognizable symptoms of downy mildew from emergence till flowering. The results obtained allowed us to identify the lines with the highest race non-specific resistance to downy mildew: VK 678(5.3\%), VK 653(7.3\%), VA $760(3.3 \%)$, VA $93(2.0 \%)$ and VK $732(6.3 \%)$. The final aim is the development of sunflower hybrids with the most durable resistance to downy mildew, combining one parental line with the major gene $\left(P l_{15}\right)$ most effective for the specific location and the second parental line with a high level of horizontal resistance to downy mildew.
\end{abstract}

Keywords: sunflower / line / resistance / downy mildew / breeding

Résumé - Évaluation de la résistance horizontale du tournesol (Helianthus annuus L.) au mildiou (Plasmopara halstedii). Le mildiou est l'une des maladies les plus importantes de la culture du tournesol dans le monde, causée par Plasmopara halstedii (Farl.) Berl.et de Toni. L'objectif de notre étude était d'évaluer la résistance horizontale au mildiou des lignées élites et prospectives dans des conditions de terrain. Les expériences ont été menées à l'Institut de recherche panrusse des oléagineux (VNIIMK) en 2016-2020. Des lignées de tournesol issues du programme de sélection du VNIIMK ont été étudiées, divisées en quatre groupes sur la base de leurs résistances race-spécifique déterminées par tests de laboratoire. Le plan expérimental était en blocs randomisés avec deux répétitions. L'évaluation a été faite en enregistrant tous les symptômes reconnaissables du mildiou, de la levée à la floraison. Les résultats obtenus nous ont permis d'identifier les lignées présentant la plus forte résistance horizontale (non spécifique d'une race du pathogène) au mildiou: VK 678(5,3\%), VK 653(7,3\%), VA $760(3,3 \%)$, VA $93(2,0 \%)$ et VK $732(6,3 \%)$. L'objectif final est le développement d'hybrides de tournesol présentant une résistance durable au mildiou, en combinant une lignée parentale avec un gène majeur de résistance $\left(P l_{15}\right)$ le plus efficace localement et une seconde lignée parentale dotée d'une résistance horizontale élevée au mildiou.

Mots clés : tournesol / lignée / résistance / mildiou / sélection

\section{Introduction}

Downy mildew (DM) is one of the most important diseases of sunflower around the world caused by Plasmopara halstedii

\footnotetext{
it Contribution to the Topical Issue "Sunflower / Tournesol".

*Correspondence: serggontchar@hotmail.com
}

(Farl.) Berl. et de Toni (Novotelnova, 1962; Goossen and Sackston, 1968; Sackston, 1992; Gulya et al., 1997; Jocić et al., 2012). There are a few ways to control DM including agrotechnical, chemical, and breeding methods. Seed chemical treatment and cultivation of resistant sunflower hybrids to DM are the most effective control measures (Gulya et al., 1997; Vear et al., 1997). Breeding for resistance to DM usually 
concentrates on the search for and incorporation of major genes designated $P l$ into elite sunflower lines. Simple inheritance of DM genes was discovered rather early (Vranceanu and Stoenescu, 1970; Zimmer, 1974), with different race-specific single dominant resistance genes used worldwide by sunflower breeders (Vear et al., 2008a). This causes the DM pathogen to evolve new races (Ahmed et al., 2012). After race 100 and 300 appeared, then 710, 730, 304, 307, 314, 334, 704 and 714 evolved (Carson, 1981; Gulya et al., 1991b; Molinero-Ruiz et al., 1998, 2002; Tourvieille de Labrouhe et al., 2000; Gulya, 2007). Now 35 Pl genes have been discovered and incorporated into commercial sunflower hybrids (Tourvieille de Labrouhe et al., 2008; Qi et al., 2016, 2019; Trojanova et al., 2017).

Identification of races is based upon the reaction of the host (an internationally accepted set of differential lines) to the pathogen (Gulya et al., 1991a; Gulya, 1995; Tourvieille de Labrouhe et al., 2000, 2012). Molecular markers have been used in P. halstedii race differentiation (Roeckel-Drevet et al., 2003; Gascuel et al., 2015) and in sunflower maker assisted selection for resistance (Mulpuri et al., 2009).

Wild sunflower species are often used as a source of new DM resistance genes (Seiler, 1992; Vear, 2004, 2010; Vear et al., 2008a; Kaya et al., 2012).

Appearance of new races forces sunflower growers to use chemical control with seed-applied fungicides. Usually, seeds are treated by metalaxyl or mefenoxam (Melero-Vara et al., 1982; Albourie et al., 1998; Gulya, 2002; Molinero-Ruiz et al., 2005). However, in 1995 metalaxyl tolerant isolates were discovered (Molinero-Ruiz et al., 2005; Spring et al., 2006) and a little later-mefenoxam-tolerant isolates (Molinero-Ruiz et al., 2005).

Durable resistance could be achieved by combining racespecific (vertical) and non-race-specific (horizontal) resistance in a single hybrid (Tourvieille de Labrouhe et al., 2004; Vear, 2004; Vear et al., 2008b). To accomplish this, it is possible to use one parental line with the most effective major gene for the specific location and the second parental line with high horizontal resistance to DM.

The aim of this study was to evaluate the horizontal resistance of elite and prospective VNIIMK breeding lines to DM under field conditions.

\section{Material and methods}

The experiments were conducted at the Central Station of All-Russia Research Institute of Oil Crops (VNIIMK), Krasnodar, Russia in 2016-2020. The Krasnodar region is situated in the Southern part of Russia near the Black Sea. Climatic conditions are very favorable for sunflower production. Sunflower production usually covers about 0.5 million ha in this region. Downy mildew is one of the most dangerous pathogens for sunflower in the region. During the last decade, new races of DM (710, 730 and later 334) (Iwebor et al., 2016) appeared to become common and all the commercial VNIIMK hybrids (resistant to only race 330 ) became susceptible to DM (Gontcharov, 2014).

Released and prospective sunflower lines of the VNIIMK breeding program were used in the study and divided into four Groups based their race-specific resistance in laboratory tests.
All lines used in the study are the property of the V.S. Pustovoit All-Russian Research Institute of Oil Crops (VNIIMK), and could be available through a specific agreement. The first Group includes 18 lines without any major genes for resistance to DM. The lines in this Group were highly susceptible to race 330 laboratory tests. The second Group included 17 lines resistant to the race 330 , but susceptible to the race 710 and 730 consisted of 17 lines resistant to the mixture of races $-330,710$ and 730 (mainly with $\mathrm{Pl}_{8}$ ). The fourth Group included five lines with $P l_{15}$, resistant to all the downymildew races identified in the region up to 2016. All the pathogen samples used in the experiment were collected in the field of the Krasnodar region and identified as to race.

The experimental design was a randomized block with two replications. Each replication had two rows for each line with an area of $12.2 \mathrm{~m}^{2}$. Seeds were not treated with any chemicals. Evaluation was made by recording all the visible symptoms of DM from emergence until flowering. Low air temperatures and an abundance of precipitation at emergence and early growth stages produced favorable conditions for the pathogen (Cohen and Sackston, 1973) in both 2016 and 2017. However, in 2018, 2019 and in 2020 they were unfavorable for DM with higher temperatures and low precipitation in the early growth stages.

\section{Results}

Many sunflower plants had DM symptoms in the field in 2016 and 2017. Favorable weather conditions stimulated the pathogen development. This allows for the identification of all the sunflower material with resistance to DM in the field without any artificial inoculation. Downy mildew infection was present in all Groups, except one, Group 4 (lines with $P l_{15}$ gene) where there was no infection (Tab. 1).

Sunflower lines from Group 2 (resistant to the race 330) were damaged to a greater extent than those from Group 1. Therefore, this major gene for resistance to DM was no longer effective. Sunflower lines from the Groups 1 and 2 were analyzed together.

Sunflower lines from Group 3 (resistant to the most frequently appearing races) were damaged by DM to a lesser extent.

The situation in the following years (2018-2020) was quite different with DM rarely occurring, indicating a low infection pressure.

Sunflower lines included in Groups 3 and 4 have major gene(s) effectively protecting them from DM attacks. Lines from Groups 1 and 2 demonstrated rather high damage rate depending on year condition and their level of horizontal resistance (Tabs. 2 and 3 ).

The results allowed for the identification of lines with the highest nonspecific race resistance to DM: VK 678(5.3\%), K 653 (7.3\%), VA 760 (3.3\%), VA 93 (2.0\%) and VK $732(6.3 \%)$. Presence of horizontal resistance can vary greatly depend on the quantity of available spores for infection and proper environmental conditions. Some lines were damaged up to $100 \%$. It demonstrates that weather conditions were favorable for the pathogen development and a sufficient quantity spores were available in the field for infection.

Similar results were obtained for the Group 2. In general estimation of sunflower resistance was close to the previous 
Table 1. Resistance of sunflower lines Groups to downy mildew (VNIIMK, Krasnodar, Russia).

\begin{tabular}{|c|c|c|c|c|c|}
\hline Group & \multicolumn{5}{|c|}{ Average percent downy mildew infection } \\
\hline $\begin{array}{l}\text { Group } 1 \\
\text { (without major genes for resistance) }\end{array}$ & 21 & 22 & 6.6 & 0.9 & 0.8 \\
\hline $\begin{array}{l}\text { Group } 2 \\
\text { (resistant to race } 330 \text { ) }\end{array}$ & 30 & 24 & 6.4 & 1.6 & 0.9 \\
\hline $\begin{array}{l}\text { Group } 4 \\
\text { (with } P l_{15} \text { gene) }\end{array}$ & 0 & 0 & 0 & 0 & 0 \\
\hline
\end{tabular}

Table 2. Evaluation of sunflower lines horizontal resistance to downy mildew (VNIIMK, Krasnodar, Russia).

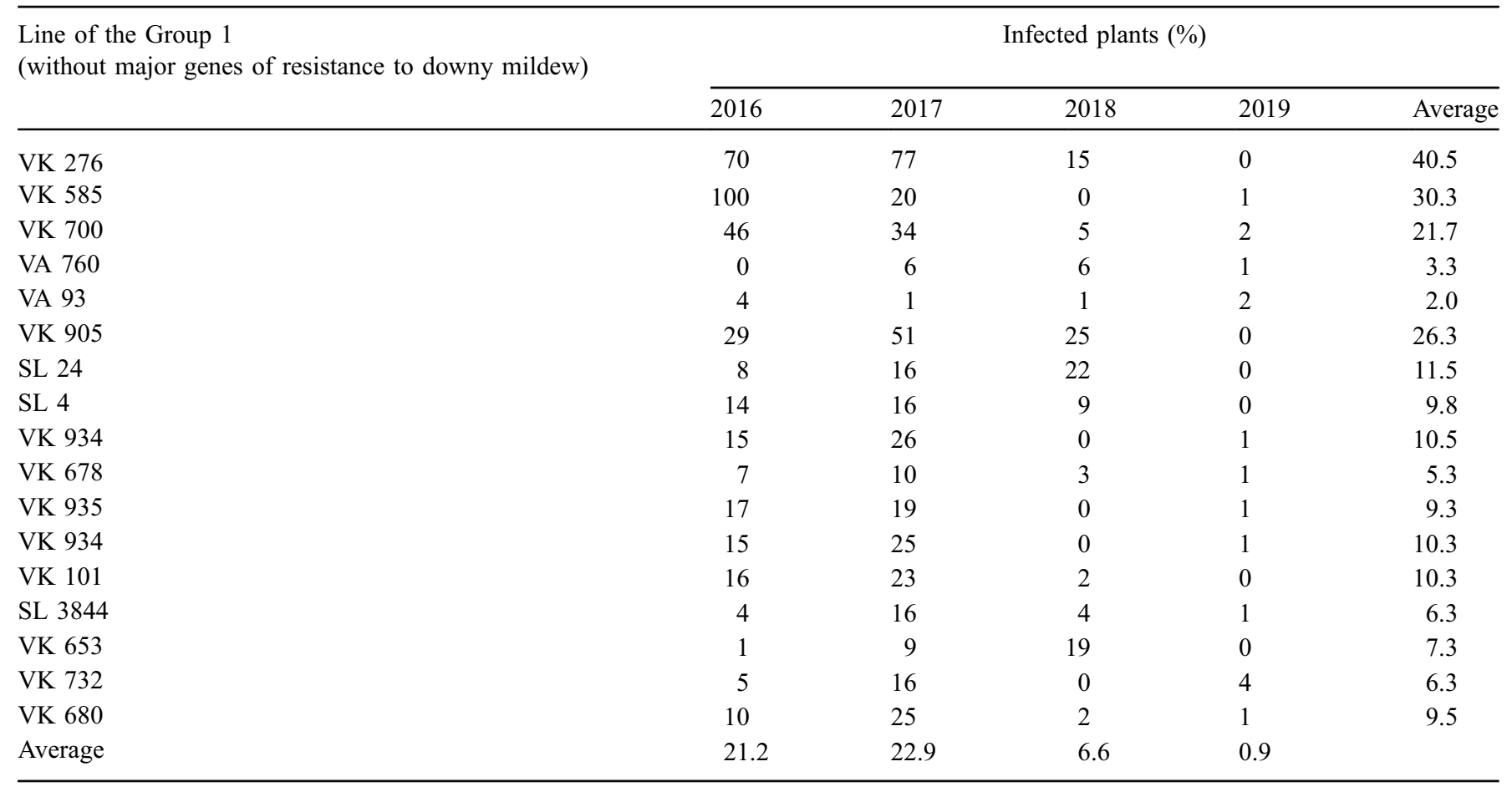

Group (Tab. 3). Race 330 is no longer the predominant race so the major gene for resistance to DM is no longer effective.

Field evaluation from the favorable years (2016 and 2017) allowed for the differentiation of susceptible lines for horizontal (race-nonspecific) resistance to DM. Lines with the less than $10 \%$ of infected plants were considered to be resistant, with 10 to $40 \%$ of infected plants, mildly resistant, and with more than $40 \%$ of infected plants susceptible (Fig. 1).

Field evaluation made in the unfavorable years (2018 and 2019) for pathogen development were not useful since all lines showed resistance (Fig. 1).

The final aim of the study was the development of sunflower hybrids with durable resistance to DM, combining one parental line with the most effective major gene $\left(P l_{15}\right.$ for example) for the specific location and the second parental line with a high horizontal resistance to DM.

\section{Discussion}

Field evaluation during favorable years showed the presence of high genetic variability for horizontal resistance to $\mathrm{DM}$ in a set of sunflower inbred lines developed by VNIIMK. This has been shown in different materials reported by other researchers (Tourvieille de Labrouhe et al., 2008; Vear et al., 2008b; Ahmed et al., 2012; Gontcharov, 2014).

To evaluate the horizontal resistance properly, it is necessary to test the number of susceptible to DM sunflower lines during at least three years in a field conditions. However, 
Table 3. Evaluation of sunflower lines horizontal resistance to downy mildew (VNIIMK, Krasnodar, Russia).

\begin{tabular}{|c|c|c|c|c|c|}
\hline \multirow{2}{*}{$\begin{array}{l}\text { Line of the Group } 2 \\
\text { (without major genes of resistance to downy mildew) }\end{array}$} & \multicolumn{5}{|c|}{ Infected plants $(\%)$} \\
\hline & 2016 & 2017 & 2018 & 2019 & Average \\
\hline VK 794 & 17 & 31 & 0 & 0 & 12.0 \\
\hline VK 551 & 13 & 3 & 5 & 0 & 5.3 \\
\hline VK 989 & 39 & 18 & 25 & 2 & 21.0 \\
\hline VK 536 & 5 & 9 & 22 & 1 & 9.3 \\
\hline VK 941 & 36 & 41 & 9 & 2 & 22.0 \\
\hline VK 776 & 6 & 36 & 0 & 0 & 10.5 \\
\hline VK 780 & 34 & 30 & 3 & 0 & 16.8 \\
\hline VK 915 & 62 & 33 & 19 & 2 & 29.0 \\
\hline VK 917 & 11 & 8 & 0 & 2 & 5.3 \\
\hline VK 920 & 44 & 29 & 2 & 2 & 19.3 \\
\hline Average & 30.1 & 24.4 & 6.6 & 1.0 & \\
\hline
\end{tabular}

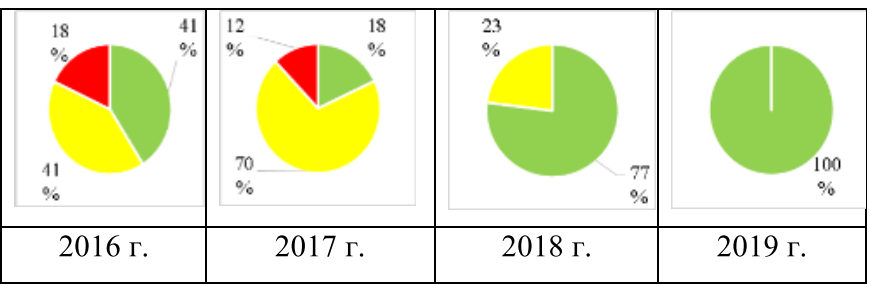

Lines from the Group 1

\begin{tabular}{|c|c|c|c|}
\hline${ }^{23}$ & $\begin{array}{l}\% \\
\% \\
\% \\
\% \\
\% \\
0\end{array}$ & 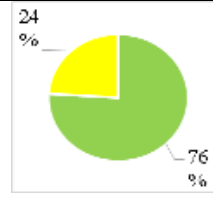 & \\
\hline 2016 г. & 2017 г. & 2018 г. & 2019 г. \\
\hline \multicolumn{4}{|c|}{ Lines from the Group 2} \\
\hline
\end{tabular}

Fig. 1. Differentiation of susceptible sunflower lines for horizontal (race nonspecific) resistance to downy mildew depending on the year. Green: Resistant, less than 10\% of damaged plants; Yellow: Medium resistant, 10 to $40 \%$ of damaged plants; Red: Susceptible, more than $40 \%$ of damaged plants.

we didn't meet any published material with such kind of information.

This study agrees with other researchers (Tourvieille de Labrouhe et al., 2004; Vear, 2004; Vear et al., 2008b) that durable resistance in sunflower could be achieved by combining race-specific (vertical) and non-race-specific (horizontal) resistance in one hybrid. To achieve this, it is possible to use one parental line with the most effective specific location gene and the second parental line with a high horizontal resistance to DM.

\section{Conclusion}

Results of this study allowed for the identification of lines with the highest nonspecific race resistance to DM: VK 678 $(5.3 \%)$, VK $653(7.3 \%)$, VA $760(3.3 \%)$, VA $93(2.0 \%)$ and VK $732(6.3 \%)$. The major $P l_{15}$ gene was highly effective in preventing DM infection. The final aim was the development of sunflower hybrids with durable resistance to DM, combining one parental line with the specific effective major $\left(P l_{15}\right)$ gene and the second parental line with a high horizontal resistance to downy mildew.

Conflicts of interest. The authors declare that they have no conflicts of interest in relation to this article.

\section{References}

Ahmed S, Tourvieille de Labrouhe D, Delmotte D. 2012. Emerging virulence arising from hybridisation facilitated by multiple introductions of the sunflower downy mildew pathogen Plasmopara halstedii. Fungal Genet Biol 49: 847-55.

Albourie JM, Tourvieille J, Tourvieille de Labrouhe D. 1998. Resistance to metalaxyl in isolates of the sunflower pathogen Plasmopara halstedii. Eur J Plant Pathol 104: 235-42.

Carson ML. 1981. New race of Plasmopara halstedii virulent on resistant sunflowers in South Dakota. Plant Dis 65: 842-3. 
Cohen Y, Sackston WE. 1973. Factors affecting infection of sunflower by Plasmopara halstedii. Can J Bot 51: 15-22.

Gascuel Q, Martinez I, Boniface M-C, Vear F, Pichon M, Godiard L. 2015. The sunflower downy mildew pathogen Plasmopara halstedii. Mol Plant Pathol 16: 109-22.

Gontcharov SV. 2014 Dynamics of hybrid sunflower disease resistance. Helia 37(60): 99-104.

Goossen PG, Sackston WE. 1968. Transmission and biology of sunflower downy mildew. Can J Bot 46: 5-10.

Gulya TJ. 1995. Proposal of a revised system of classifying races of sunflower downy mildew. In: Proceedings of 17th Sunflower Research Workshop, Fargo, ND, USA, National Sunflower Association, pp. 76-78.

Gulya TJ. 2002. Efficacy of single and two-way fungicide seed treatments for the control of metalaxyl-resistant strains of Plasmopara halstedii (sunflower downy mildew). In: Proceedings of the BCPC Conference Pests and Diseases, Brighton, UK, BCPC, pp. 575-80.

Gulya TJ. 2007. Distribution of Plasmopara halstedii races from sunflower around the world. In: Lebeda A, Spencer-Phillips PTN, eds. Advances in Downy Mildew Research, Vol. 3. Proceedings of the 2nd International Downy Mildews Symposium at Palacky University in Olomouc and JOLA, Kostelecna Hane, Czech Republic. Dordrecht, Netherlands: Springer, pp. 121-34.

Gulya TJ, Miler JF, Viranyi F, Sackston WE. 1991a. Proposed internationally standardized method for race identification of Plasmopara halstedii. Helia 14: 11-20.

Gulya TJ, Sackston WE, Viranyi F, Masirevic S, Rashid KY. 1991 b. New races of the sunflower downy mildew pathogen (Plasmopara halstedii) in Europe and North and South America. J Phytopath 132: 303-11.

Gulya TJ, Rashid KY, Masirevic SM. 1997. Sunflower diseases. In: Schneiter AA, ed. Sunflower Technology and Production. Agronomy No.35. Madison, WI, USA: American Society of Agronomy, pp. 263-379.

Iwebor M., Antonova TS, Saukova S. 2016. Changes in the racial structure of Plasmopara halstedii (Farl.) Berl. et de Toni population in the South of the Russian Federation. Helia 39 (64): 113-121.

Jocić S, Miladinović D, Imerovski I, et al. 2012. Towards sustainable downy mildew resistant in sunflower. Helia 35(56): 61-72.

Kaya Y, Jocic S, Miladinovic D. 2012 Sunflower. In: Gupta SK, ed. Technological Innovations in Major World Oil Crops, V.1, pp. 85-129.

Melero-Vara JM, Garcia-Baudin C, Lopez-Herrera CJ, Jimenez-Diaz RM. 1982. Control of sunflower downy mildew with metalaxyl. Plant Dis 66: 132-5.

Molinero-Ruiz L, Melero-Vara JM, Gulya TJ. 1998. Pathogenic characterization of Plasmopara halstedii isolates from Spain. In: Gulya TJ, Vear F, eds. Proceedings of the International Sunflower Association Symposium III, Sunflower Downy Mildew, Fargo, ND, USA, International Sunflower Association, pp. 26-9.

Molinero-Ruiz ML, Dominguez J, Melero-Vara JM. 2002. Races of isolates of Plasmopara halstedii from Spain and studies on their virulence. Plant Dis 86: 736-40.

Molinero-Ruiz ML, Dominguez J, Gulya TJ, Melero-Vara JM. 2005. Reaction of field populations of sunflower downy mildew (Plasmopara halstedii) to metalaxyl and mefenoxam. Helia 28: 66-74.

Mulpuri S, Liu Z, Feng J, Gulya TJ, Jan C-C. 2009. Inheritance and molecular mapping of a downy mildew resistance gene $P l_{13}$ in cultivated sunflower (Helianthus annuus L.). Theorl Appl Genet 119: 795-803.
Novotelnova NS. 1962. Plasmopara halstedii as a composite species (the basis for the taxonomic division of the genus Plasmopara on Compositae). Bot Zhurnal (Moscow and Leningrad) 47: 970-81.

Qi LL, Foley ME, Cai XW, Gulya TJ. 2016. Genetics and mapping of a novel downy mildew resistance gene, $P l_{18}$, introduced from wild Helianthus argophyllus into cultivated sunflower (Helianthus annuus L.). Theorl Appl Genet 129: 741-52.

Qi LL, Ma GJ, Li XH et al. 2019. Diversification of the downy mildew resistance gene pool by introgression of a new gene, $\mathrm{Pl}_{35}$, from wild Helianthus argophyllus into oilseed and confection sunflowers (Helianthus annuus L.). Theor Appl Genet 132: 25532565. https://doi.org/10.1007/s00122-019-03370-9.

Roeckel-Drevet P, Tourvieille J, Gulya TJ, Charmet G, Nicolas P, Tourvieille de Labrouhe D. 2003. Molecular variability of sunflower downy mildew, Plasmopara halstedii, from different continents. Can J Microbiol 49: 492-502.

Sackston WE. 1992. On a treadmill: Breeding sunflowers for resistance to disease. Ann Rev Phytopathol 30: 529-51.

Seiler GJ. 1992. Utilization of wild sunflower species for the improvement of cultivated sunflower. Field Crops Res 30: 195230.

Spring O, Zipper R, Heller-Dohmen M. 2006. First report of metalaxyl resistant isolates of Plasmopara halstedii on cultivated sunflower in Germany. J Plant Dis Protect 113: 224.

Trojanova Z, Sedlarova M, Gulya TJ, Lebeda A. 2017. Methodology of virulence screening and race characterization of Plasmopara halstedii, and resistance evaluation in sunflower-A review. Plant Pathol 66(2): 171-185.

Tourvieille de Labrouhe D, Gulya T, Masirevic S, et al. 2000. New nomenclature of races of Plasmopara halstedii (sunflower downy mildew). In: Proceedings of the 15th International Sunflower Conference, Toulouse, France, International Sunflower Association, pp. 61-6.

Tourvieille de Labrouhe D, Walser P, Mestries E, Penaud A, Tardin MC, Pauchet I. 2004. Sunflower downy mildew resistance gene pyramiding, alternation and mixture: First results comparing the effects of different varietal structures on changes in the pathogen. In: Proc. 16th Int. Sunflower Conf., Fargo, USA, 255 p.

Tourvieille de Labrouhe D, Serre F, Walser P, Roche S, Vear F. 2008. Quantitative resistance to downy mildew (Plasmopara halstedii) in sunflower (Helianthus annuus L.). Euphytica 164: 433-44.

Tourvieille de Labrouhe D, Walser P, Jolivot D et al. 2012. Proposal for improvement of sunflower downy mildew race nomenclature. In: Proc. of the 18th Int. Sunflower Conf., Mar del Plata, Argentina. Available from https://www.researchgate.net/publica tion/283266439_Proposal_for_improvement_of_sunflower_dow ny_mildew_race_nomenclature (last consult: $2016 / 01 / 03$ ).

Vear F. 2004. Breeding for durable resistance to the main diseases of sunflower. In: Proc. 17th Int. Sunflower Conf., Fargo, USA, pp. $125-130$.

Vear F. 2010. Classic genetics and breeding. In: Hu J, Seiler G, Kole $\mathrm{C}$, eds. Genetics, genomics and breeding of sunflower. Enfield, NH, USA: Science Publishers, pp. 51-78.

Vear F, Gentzbittel L, Philippon J, et al. 1997. The genetics of resistance to five races of downy mildew (Plasmopara halstedii) in sunflower (Helianthus annuus L.). Theorl Appl Genet 95: 584-9.

Vear F, Serieys H, Petit A, et al. 2008a. Origins of major genes for downy mildew resistance in sunflower. In: Proceedings of 17th International Sunflower Conference, Cordoba, Spain, Consejeria de Agricultura y Pesca, pp. 125-30.

Vear F, Serre F, Jouan-Dufournel I, et al. 2008b. Inheritance of quantitative resistance to downy mildew (Plasmopara halstedii) in sunflower (Helianthus annuus L.). Euphytica 164: 561-70. 
Vranceanu V, Stoenescu F. 1970. Immunity to sunflower downy mildew due to a single dominant gene. Probl Agric 22: $34-40$.
Zimmer DE. 1974. Physiological specialization between races of Plasmopara halstedii in America and Europe. Phytopathology 64: 1465-7.

Cite this article as: Gontcharov S, Goloschapova N. 2021. Evaluation of horizontal resistance of sunflower (Helianthus annuus L.) to downy mildew (Plasmopara halstedii). OCL 28: 58. 